\title{
Association between renal stones and renal cell carcinoma
}

\author{
A. M. Abeygunasekera \\ Department of Urology, Karapitiya Teaching Hospital, Galle.
}

To the Editors,

Renal cell cancer is listed as a complication of renal stones in almost all text books of urology and general surgery. However its incidence and the degree of association are not documented. Over a period of nine years about 1000 open renal operations were done for large renal stones at the Urology Unit, Karapitiya Teaching Hospital, Galle. During this period of time we have seen two patients with renal cell cancer and large stones. One was a squamous cell carcinoma and the other was a sarcomatiod renal cell carcinoma. Both patients had large staghorn calculi. During this period a large number (about 8000) of patients with small renal stones (less than $2 \mathrm{~cm}$ ) were treated but no malignancies were seen.

Though the numbers are small this makes the incidence of renal malignancy in patients with large renal stones to be about 1 in 500. Furthermore stones smaller than $2 \mathrm{~cm}$ may not be associated with malignancies. We hope more urological surgeons would share their experience in this regard so that we would know better about the association between renal stones and renal malignancies. 